\begin{tabular}{|c|c|c|}
\hline & JHE 5 (2) (2020) 78-85 & $=$ \\
\hline & Journal of Health Education & \\
\hline $\begin{array}{l}\text { Journal of } \\
\text { HealthEducation }\end{array}$ & http://journal.unnes.ac.id/sju/index.php/jhealthedu & $=$ \\
\hline
\end{tabular}

\title{
Consumption of Fried Foods as A Risk Factor for Hypercholester- olemia: Study of Eating Habits in Public Health Students
}

\author{
Hesti Yuningrum ${ }^{\bowtie}$, Merita Eka Rahmuniyati, Naomi Nisari Rosdewi Sumiratsi
}

DOI: http://dx.doi.org/10.15294/jhe.v5i2.38683

Universitas Respati Yogyakarta, Indonesia

\section{History Article \\ Submitted 12 May 2020 \\ Revised 11 July 2020 \\ Accepted 24 September 2020}

\section{Keywords}

hypercholesterolemia; public health; students

\begin{abstract}
Background: Students in the health sector should have more health literacy so that they can show better health practices as well. However, unfortunately, a preliminary study on students in the field of public health showed that almost $50 \%$ of students have eating habits and physical activity that was not following health recommendations. The behavior of consuming fried foods in this group of students can be a risk factor for hypercholesterolemia. For this reason, it is necessary to study the habit of consuming fried foods as a risk factor for hypercholesterolemia.

Method: The study was using analytical research with a cross-sectional design. The sampling technique used a purposive sampling method. The minimum sample size is 91 people. Data analysis used univariate, bivariate using chi-square test, and multivariate using logistic regression.

Results: The results of the bivariate analysis showed significant results, namely BMI $(\mathrm{RP}=2.20 ; 95 \% \mathrm{CI}=1.09-4.43 ; \mathrm{p}=0.03)$. Consumption of fried foods $(\mathrm{RP}=3.33$; $95 \% \mathrm{CI}=1.69-6.57 ; \mathrm{p}=0.001)$. Physical activity $(\mathrm{RP}=2.23 ; 95 \% \mathrm{CI}=1.04-4.79 ; \mathrm{p}=$ $0.03)$. The result of the bivariate analysis that was not significant was smoking $(\mathrm{RP}=$ $1.28 ; 95 \% \mathrm{CI}=0.55-2.98 ; \mathrm{p}=0.547)$. The results of multivariate analysis showed that the most influencing risk factor for hypercholesterolemia was fried food consumption $(\mathrm{RP}=5.42 ; 95 \% \mathrm{CI}=1.18-16.21 ; \mathrm{p}=0.003)$.

Conclusion: The factors associated with hypercholesterolemia are BMI, consumption of fried foods, and physical activity. The most influencing risk factor for hypercholesterolemia is the consumption of fried foods.
\end{abstract}

\section{How to Cite}

Yuningrum, H., Rahmuniyati, M. E., \& Sumiratsi, N. N. R. (2020). Consumption of Fried Foods as A Risk Factor for Hypercholesterolemia: Study of Eating Habits in Public Health Students. JHE (Journal of Health Education), 5(2), 78-85.

\footnotetext{
${ }^{\square}$ Corresponding Author:
}

J1. Raya Tajem Km.1,5 Maguwoharjo, Depok, Sleman

p-ISSN 2527-4252

E-mail: hesti.yuningrum.siregar@gmail.com 


\section{INTRODUCTION}

Indonesia is currently facing a double burden disease, namely communicable diseases and non-communicable diseases (NCD). The increase in the burden due to NCD is in line with the increase in risk factors such as blood pressure, blood sugar, body mass index or obesity, unhealthy diet, lack of physical activity, and smoking and alcohol.

NCD used to be a disease that is synonymous with old age, nowadays many people at a young age suffer from this disease. This disease is often associated with diseases of the elderly, but in fact the disease can strike at a young age. Experts state that NCD in adolescents can be caused by many factors, including poor/unhealthy diet or diet, environmental influences, including smoking and alcoholic beverages, and heredity. According to the results of the Global School-based Student Health Survey (GSHS) or a school-based global health survey in 2015 , it is known that the current lifestyle of adolescents is at risk of noncommunicable diseases. The unhealthy diet is wherein one day adolescents consume fast food $(53 \%)$, less consumption of vegetables and fruit (78.4\%), soft drinks (28\%), less physical activity $(67.9 \%)$, have smoked $(22.5 \%)$, and consumed alcohol (4.4\%). The results of the Riskesdas (2018) showed $26.1 \%$ of youth did not do physical activity. Meanwhile, as many as $93.5 \%$ of the population aged 10 years and over consume fewer vegetables and fruit, and around $36.3 \%$ of Indonesians aged 15 years and over smoke. This lifestyle has an impact on the possibility of heart disease, hypertension, diabetes, and stroke (Kemenkes, 2018).

The results of Riskesdas showed that there was an increase in the key indicators of NCD listed in the 2015-2019 RPJMN, as the prevalence of high blood pressure in the population aged 18 years and over increased from $25.8 \%$ to $34.1 \%$, the obesity prevalence of the population aged 18 years and over increased from $14.8 \%$ to $21.8 \%$, the smoking prevalence of the population aged $\leq 18$ years increased from $7.2 \%$. to $9.1 \%$ (Kemenkes, 2018).

One example of NCD is cardiovascular disease which is a major cause of death in many developed countries. Cardiovascular disease has now become a cause of death in developing countries, including Indonesia. Cardiovascular disease, especially coronary heart disease (CHD), is a cause that needs more attention in developing countries. A study by Dahm (2016) showed that high-quality diet in adolescence, as measured by adherence to the Alternative Healthy Eating Inde (AHEI) during high school, is associated with a lower risk of developing cardiovascular disease risk factors during mid-adulthood (Dahm et al., 2016). High plasma total cholesterol levels, arterial hypertension, and smoking habits are the 3 main risk factors for $\mathrm{CHD}$. Hypercholesterolemia occupies a very important part because hypercholesterolemia is the only risk factor that can cause atherosclerosis. World Health Organization (WHO) estimates that hypercholesterolemia is associated with more than half of the incidence of coronary heart disease and more than four million deaths each year (Hatma, 2016). Hypercholesterolemia risk factors can be divided into 2 , namely uncontrollable factors such as age and heredity, as well as controllable factors such as obesity, cholesterol intake, high fat intake, low fiber intake, smoking, lack of physical activity, and high blood sugar levels (Hanum, 2016). One of the risk factors for hypercholesterolemia is the consumption of fried foods. Fries is one of the foods that is fried using oil so that it has a crunchy, savory, and delicious taste and is supported at an affordable price. The frying process using oil repeatedly can make calorie and fat content in food much increase. Indonesians mostly consume fried foods that contain saturated fat. Saturated fats are known as bad fats, which are at risk of clogging blood circulation. The main cause of increasing cholesterol levels in the blood is the frequent consumption of foods containing high cholesterol and high saturated fat (Hanum, 2016).

Body mass index (BMI) values reflect a person's body image. Mild and moderate overweight with a BMI value above 25.1 has a tendency for cholesterol levels to be $30 \%$ higher than respondents who have normal weight (Soleha, 2016). Other risk factors for hypercholesterolemia are smoking and lack of physical activity. The more cigarettes smoked per day, the total cholesterol will also increase (Shirazi, 2016). Duration of smoking also has a significant relationship with the risk of hypercholesterolemia. People who have smoking habits $>15$ years have a 2.8 times risk compared with people who have smoking habits $\leq 15$ years. Apart from smoking, lack of physical activity also affects cholesterol levels. The risk of hypercholesterolemia was found more in respondents who had light activity than respondents who had heavy activity. Based on the results of previous research, it shows a significant relationship between physical activity and total cholesterol levels with $\mathrm{r}=-0.349$ and $\mathrm{p}=<0.001$ (Zuhroiyyah, et al., 2017).

Based on a preliminary study that was con- 
ducted through interviews with 20 students of the Public Health Study Program, it was found that students had habits that triggered the risk of hypercholesterolemia. Some of the habits carried out are consuming fried foods (55\%), less physical activity (65\%), and smoking (50\%). The purpose of this study was to determine the factors associated with hypercholesterolemia in students of the Public Health Study Program, Universitas Respati Yogyakarta.

\section{METHODS}

This research is an analytical study with a cross-sectional design. This research was conducted on campus 2 of Universitas Respati Yogyakarta, in January 2020. The population in this study were all public health study program students at Universitas Respati Yogyakarta. The sample in this study were some of the public health study program students who met the inclusion criteria. The sampling method used was purposive sampling, with inclusion and exclusion criteria. Inclusion criteria are students of the 2016 class of public health study programs, willing to become respondents by giving informed consent, do not undergo low cholesterol or low fat diet such as people with Diabetes Mellitus (DM) and CHD. Exclusion criteria are respondents who took cholesterol-lowering drugs, had just stopped smoking 3 days before. The sample size was calculated using sample size software to test the two-proportion hypothesis, and the minimum sample size was 91 people. The variables studied were BMI, fiber intake, smoking, physical activity, and consumption of fried foods.

The instruments used in this study were Semi Quantitative Food Frequency Questionnaire (SQFFQ) was used to collect data on the consumption of fried foods. The Global Physical Activity Questionnaire is used to collect physical activity data. The GPAQ questionnaire is the standard questionnaire from $\mathrm{WHO}$ to assess a person's physical activity. According to WHO, the Global Physical Activity Questionnaire (GPAQ) is an instrument developed by WHO for monitoring physical activity in developing countries. The GPAQ consists of 16 questions that collect information about physical activity in three domains namely physical activity at work, travel activities to and from work, and recreational or leisure activities. Metabolic Equivalents (MET) are used to measure the intensity of physical activity and to analyze GPAQ data.

Digital body scales are used to measure body weight. Microtoise is used to measure the respondents' height. Cholesterol rapid test (Easy Touch) to see the total cholesterol of the respondent. Data analysis used univariate, bivariate using the chi-square test to determine statistical significance, and multivariate using logistic regression to see the most influential variables.

This research has received permission from the Research Ethics Commission of the Universitas Respati Yogyakarta No. 004.3/FIKES/ $\mathrm{PL} / 1 / 2020$. When the research was carried out, all subjects were given an explanation of the research objectives and the process at the time of the interview. All data and information obtained will be kept confidential and only used for research purposes. Respondents who are willing will sign an informed consent statement.

\section{RESULTS AND DISCUSSION}

\section{Distribution of Respondent Characteristics}

The total number of respondents in this study amounted to 91 people. The characteristics of the respondents studied included age and gender. The characteristics of the research respondents can be seen in the Table 1.

Table 1. Respondents Characteristics

\begin{tabular}{lcc}
\hline Variable & Total (n) & Percentage (\%) \\
\hline Age & & \\
20-22 years old & 81 & 89 \\
23-25 years old & 10 & 11 \\
\hline Gender & & \\
Female & 68 & 74.7 \\
Male & 23 & 25.3 \\
\hline
\end{tabular}

Based on age, most of the respondents were in the age category of 20-22 years as many as 81 people (89\%). based on gender most of the respondents were female as many as 68 people (74.7\%).

\section{Univariate Analysis}

The variables studied were hypercholesterolemia, BMI, smoking, physical activity, and consumption of fried foods. Based on Table 2, it can be seen that total cholesterol levels in the hypercholesterolemic category were 22 people $(24.2 \%)$. BMI in the risk category $(>25 \mathrm{~kg} / \mathrm{m} 2)$ as many as 25 people $(27.5 \%)$. The risk of active smoking habit was 17 people (18.7\%). Physical activity in the risk category $(\leq 600-1500$ MET minutes/week) was 40 people (44\%). Consumption of fried foods in the risk category ( $\geq 67$ grams/ day) was 21 people $(23.1 \%)$. The results of the 
univariate analysis can be seen in the Table 2 .

\section{Bivariate Analysis}

Bivariate analysis was conducted to determine the relationship between each independent variable and the dependent variable using the chisquare test to determine statistical significance. The strength of the relationship was seen using a Ratio Prevalence (RP) with a Confident Interval (CI) of $95 \%$. The results of the bivariate analysis can be seen as Table 3 .

\section{Relationship between BMI and Hypercholes- terolemia}

Respondents who had a risky BMI (BMI $>25 \mathrm{~kg} / \mathrm{m} 2$ ) and had hypercholesterolemia were 10 people $(40 \%)$ while respondents who had no risk on $\mathrm{BMI}(\mathrm{BMI} \leq 25 \mathrm{~kg} / \mathrm{m} 2)$ and had hypercholesterolemia were 12 people $(18.2 \%)$ making it possible if cholesterol levels can be high in each individual, regardless of whether the person is obese or non-obese. Although several previous studies have found that cholesterol levels are related to body weight and BMI, cholesterol synthesis is also influenced by many factors. Other factors that can affect plasma cholesterol levels apart from hereditary factors are an increase in high cholesterol intake, a diet high in saturated fat, a diet high in unsaturated fatty acids, and a deficiency in insulin and thyroid hormones and lipoprotein disorders. Hereditary factors have the greatest role in determining a person's serum cholesterol levels, such as a gene mutation disorder at the LDL receptor that causes the formation of high LDL. Food intake and environmental factors such as physical activity, smoking also affect cholesterol levels (Hastuty, 2018).

The results of the bivariate analysis showed that BMI with risk categories obtained $\mathrm{RP}=$ $2.20,95 \%$ CI (Confident Interval) $=1.09-4.43$ and $\mathrm{p}=0.03$. The results of this analysis can be concluded that people who have a BMI $>25 \mathrm{~kg} / \mathrm{m} 2$ have a 2.20 times greater risk of suffering from hypercholesterolemia compared to people whose BMI is $\leq 25 \mathrm{~kg} / \mathrm{m} 2$. BMI has a significant relationship with hypercholesterolemia $(\mathrm{p}<0.05)$. People who are obese or overweight can increase cholesterol levels. A person who is overweight has higher levels of total cholesterol, LDL, and triglycerides compared to normal body weight (Sudargo, et al., 2017). The prevalence of hypercholesterolemia was higher in individuals with overweight/obese versus normal BMI (Subhan \& Chan, 2019).

Obesity shows that in the body and the blood there is enough fat to be stored. Obesity can lead to high cholesterol, heart disease, diabetes, and other serious diseases. Obesity is an increase in cholesterol in the blood (WHO, 2015). Obesity can increase the risk of atherosclerosis (narrowing and hardening of the arteries) and tends to have high cholesterol levels and low HDL levels (Zuhroiyyah, et al., 2017). This is supported by previous research, it was found that a high BMI is at risk of having high total cholesterol levels of 4.643 times compared to respondents with the normal BMI category (Sari, 2016).

Table 2. Results of Univariate Analysis

\begin{tabular}{lcc}
\hline Variable & Total (n) & Percentage (\%) \\
\hline Total Cholesterol Levels & & \\
Hypercholesterolemia & 22 & 24.2 \\
Normal & 69 & 75.8 \\
\hline BMI & & \\
Risk $\left(>25 \mathrm{~kg} / \mathrm{m}^{2}\right)$ & 25 & 27.5 \\
No risk $\left(\leq 25 \mathrm{~kg} / \mathrm{m}^{2}\right)$ & 66 & 72.5 \\
\hline Smoking habit & & \\
Smoking & 17 & 18.7 \\
Do not smoke & 74 & 81.3 \\
\hline Physical Activity & & \\
Risk ( $\leq 600-1500$ MET minutes/week) & 40 & 44 \\
No risk (>1500 MET minutes/week) & 51 & 56 \\
\hline Fried Food Consumption & & \\
Risk $(\geq 67$ gram/day) & 21 & 23.1 \\
No risk (<67 gram/day) & 70 & 76.9 \\
\hline
\end{tabular}


Table 3. Results of Bivariate Analysis

\begin{tabular}{|c|c|c|c|c|c|c|c|c|}
\hline \multirow[b]{2}{*}{ Variable } & \multicolumn{4}{|c|}{ Total Cholesterol Levels } & \multirow{2}{*}{$\begin{array}{c}\mathrm{p}- \\
\text { value }\end{array}$} & \multirow[t]{2}{*}{$\mathrm{RP}$} & \multicolumn{2}{|c|}{ CI $95 \%$} \\
\hline & Hypercholesterolemia & $\%$ & Normal & $\%$ & & & Lower & Upper \\
\hline $\mathrm{BMI}$ & & & & & & & & \\
\hline $\begin{array}{l}\text { Risk } \\
\left(\text { BMI > }>25 \mathrm{~kg} / \mathrm{m}^{2}\right)\end{array}$ & 10 & 40 & 15 & 60 & 0.030 & 2.20 & 1.09 & 4.43 \\
\hline $\begin{array}{l}\text { No risk } \\
\left(\mathrm{BMI} \leq 25 \mathrm{~kg} / \mathrm{m}^{2}\right)\end{array}$ & 12 & 18.2 & 54 & 81.8 & & & & \\
\hline Smoking Habits & & & & & & & & \\
\hline Smoking & 5 & 29.4 & 12 & 70.6 & 0.547 & 1.28 & 0.55 & 2.98 \\
\hline Do not smoke & 17 & 23 & 57 & 77 & & & & \\
\hline Physical Activity & & & & & & & & \\
\hline $\begin{array}{l}\text { Risk } \\
(\leq 600-1500 \text { MET } \\
\text { minutes/week) }\end{array}$ & 14 & 35 & 26 & 65 & 0.033 & 2.23 & 1.04 & 4.79 \\
\hline $\begin{array}{l}\text { No risk } \\
\text { (>1500 MET min- } \\
\text { utes/week) }\end{array}$ & 8 & 15.7 & 43 & 84.3 & & & & \\
\hline $\begin{array}{l}\text { Fried Food Con- } \\
\text { sumption }\end{array}$ & & & & & & & & \\
\hline $\begin{array}{l}\text { Risk } \\
(\geq 67 \text { grams/day) }\end{array}$ & 11 & 52.4 & 10 & 47.6 & 0.001 & 3.33 & 1.69 & 6.57 \\
\hline $\begin{array}{l}\text { No risk } \\
(<67 \text { grams/day) }\end{array}$ & 11 & 15.7 & 59 & 84.3 & & & & \\
\hline
\end{tabular}

The Relationship of Smoking with Hypercholesterolemia

Respondents who smoked and had hypercholesterolemia were 5 people $(29.4 \%)$ while respondents who did not smoke and had hypercholesterolemia were 17 people $(29.4 \%)$. This is because most of the respondents are female and do not smoke, while only a small proportion of smokers are male. This study is in line with research (Sudargo, et al., 2017) which also showed that there was no significant relationship between smoking and hypercholesterolemia.

The results of the bivariate analysis between smoking and hypercholesterolemia obtained a value of $\mathrm{RP}=1.28,95 \% \mathrm{CI}=0.55-2.98$, and $p=0.547$. The results of this analysis can be concluded that people who smoke have a 1.28 times greater risk of suffering from hypercholesterolemia than people who do not smoke. Smoking statistically did not have a significant relationship with hypercholesterolemia $(p=>0.05)$ but smoking has a risk of hypercholesterolemia. Smoking can increase blood cholesterol levels. Smoking habits will reduce HDL cholesterol levels in the bloodstream and make blood clots easily, thereby increasing the likelihood of artery blockage, heart attacks, and strokes (Zuhroiyyah, et al., 2017). Several studies have shown that smoking can in- crease LDL cholesterol levels and reduce HDL cholesterol. High nicotine levels in the blood can also lead to abnormalities in blood vessels that have an impact on health problems (Sudargo, et al., 2017). Nicotine, which is the main component of cigarettes, can increase the secretion of catecholamines, thereby increasing lipolysis. This causes increased levels of triglycerides, cholesterol, and VLDL, and reduces HDL levels. Smoking can also cause an increase in the oxidation of LDL cholesterol which will cause atherosclerosis (Cariappa, 2017).

Previous research also stated that the more cigarettes smoked, the higher the total cholesterol level (Sudargo, et al., 2017). Research by Trivedi (2016) stated that total cholesterol levels are higher in smokers compared to non-smokers. An insignificant increase in total cholesterol levels was found in light smokers, whereas a significant increase was found in moderate and heavy smokers (Trivedi \& Anand, 2016).

\section{Relationship between Physical Activity and Hypercholesterolemia}

Respondents with risky physical activity ( $\leq 600-1500$ MET minutes/week) and hypercholesterolemia were 14 people $(35 \%)$. The results of bivariate analysis between physical activity 
and hypercholesterolemia obtained $\mathrm{RP}=2.23$, $95 \% \mathrm{CI}=1.04-4.79$ and $\mathrm{p}=0.03$. The results of this analysis can be concluded that people who have physical activity $\leq 600-1500$ MET minutes/ week have a 2.23 times greater risk of suffering from hypercholesterolemia compared to people who have physical activity >1500 MET minutes/ week. Physical activity has a significant relationship with hypercholesterolemia $(p=<0.05)$. This shows that physical activity affects a person's LDL and HDL levels. If a person does not do physical activity, it can increase LDL levels and reduce HDL levels (Sudargo, et al., 2017).

Physical activity includes all daily activities including sports, activities at home, workplace, and activities while traveling such as going from home to work (Zuhroiyyah, et al., 2017). One of the physical activities is exercise because it can lower blood cholesterol levels if the exercise lasts more than 30 minutes or about 1 hour with sufficient intensity. Fat is stored in fat cells as triglycerides, exercise can break down triglyceride deposits and release fatty acids and glycerol into the bloodstream. If the exercise is carried out for a long time then fatty acids are useful as a source of fuel for the muscles. After 40 minutes of exercise, free fatty acids supply $40 \%$ of the required fuel. People who have been trained, their bodies can take $50-85 \%$ of the energy needed for exercise from fat (Sudargo, et al. 2017). Regular exercise is also effective in reducing total cholesterol levels and can increase HDL cholesterol in patients with hypercholesterolemia (Shirazi, 2006).

Physical activity can reduce LDL levels and total cholesterol levels, this is evidenced by research conducted by Zuhroiyyah (2017) showing a relationship between physical activity and total and LDL cholesterol levels with $p=0.001$ (Zuhroiyyah et al., 2017). Research by Agustianti (2017) showed a relationship between physical activity and blood cholesterol levels (Agustiyanti, 2017). Research by Kurniawati (2015) also proved that there was a relationship between physical activity and blood cholesterol levels $(p=0.013)$ and LDL cholesterol ( $p=0.021$ ) (Kurniawati, 2015). In the study by Waloya (2016) stated that the level of physical activity had a significant effect on blood cholesterol levels with a $p$ value $<0.05$ (Waloya, 2016). Regular sports training program combined with little influence of their eating habits outside school seem to contribute to a better metabolic profile and reduction in cardiovascular (i.e high-cholesterol) risk factors in students (Scherr et al., 2018)

\section{The Relationship between Consumption of Fried Foods with Hypercholesterolemia}

Respondents who consumed risky fried foods ( $\geq 67$ grams/day) and had hypercholesterolemia were 11 people $(52.4 \%)$. The results of the bivariate analysis between the consumption of fried foods and hypercholesterolemia obtained $\mathrm{RP}=3.33,95 \% \mathrm{CI}=1.69-6.57$, and $\mathrm{p}=0.001$. The results of this analysis can be concluded that people who eat fried foods $\geq 67$ grams/day have a 3.33 times greater risk of suffering from hypercholesterolemia than people who eat fried foods $<67$ grams/day. Consumption of fried foods has a significant relationship with hypercholesterolemia $(p=<0.05)$. This is because people's favorite eating fried foods are still quite high. In fact, these foods have a higher fat content, including saturated fat content. Saturated fats are known as bad fats, which are at risk of clogging blood circulation. A good diet can reduce the risk of hypercholesterolemia, it is stated in Dahm's (2016) study that women with a healthy diet measured by high Alternative Healthy Eating Index (AHEI) scores had a $16 \%$ lower risk of hypercholesterolemia women with low AHEI (Dahm et al., 2016).

The body needs a little cholesterol, but if you get too much saturated fat and cholesterol in the fried foods we eat, it can increase the levels of bad cholesterol (LDL / Low Density Lipoprotein). The research done by Ruiz (2015) stated that eating lunch (morning snack) was related with $63 \%$ lower risk of H-LDL, take food away from home once or twice a week was associated with a fourfold increased risk of H-LDL, and subjects who reported consuming excess food (1 or 2 , and 3 or more times/week) had higher risk of H-LDL (Ruiz et al., 2015). LDL cholesterol can cause plaque buildup in the arteries which results in coronary heart disease. Food sources that can trigger cholesterol, of course, fatty foods and contain lots of oil, namely fried foods that are often eaten. High LDL cholesterol causes constriction of blood vessels due to consuming fried foods rich in saturated fat (Hanum, 2016). Research by Sudargo (2017) showed that there is a significant relationship between the type of fried food $(p=0.047)$, the number of fried foods $(p=0.013)$, and the intake of fat from fried foods (0.036) and dyslipidemia (Sudargo, et al., 2017). On the other hand, findings from the study showed that individuals who do not have any chronic non-communicable diseases had lower diet quality compared with those who have at least one such disease, these results refer to a crosssectional analysis hampering cause-and-effect conclusions (Mello et al., 2020). 
Table 4. Results of Multivariate Analysis

\begin{tabular}{|c|c|c|c|}
\hline Variable & $\begin{array}{l}\text { Model } 1 \\
\text { RP } \\
\text { CI 95\% } \\
\text { p-value }\end{array}$ & $\begin{array}{l}\text { Model } 2 \\
\text { RP } \\
\text { CI 95\% } \\
\text { p-value }\end{array}$ & $\begin{array}{l}\text { Model } 3 \\
\text { RP } \\
\text { CI 95\% } \\
\text { p-value }\end{array}$ \\
\hline \multicolumn{4}{|l|}{ BMI } \\
\hline Risk & $\begin{array}{l}1.73 \\
(0.55-5.40) \\
0.34\end{array}$ & $\begin{array}{l}1.97 \\
(0.65-6.04) \\
0.23\end{array}$ & \\
\hline \multicolumn{4}{|c|}{ Physical activity } \\
\hline Risk & $\begin{array}{l}2.38 \\
(0.81-6.94) \\
0.11\end{array}$ & & $\begin{array}{l}2.55 \\
(0.88-7.35) \\
0.082\end{array}$ \\
\hline \multicolumn{4}{|c|}{ Fried Food Consumption } \\
\hline Risk & $\begin{array}{l}4.68 \\
(1 / 50-14.57) \\
0.008^{*}\end{array}$ & $\begin{array}{l}4.87 \\
(1.59-14.84) \\
0.005^{*}\end{array}$ & $\begin{array}{l}5.42 \\
(1.18-16.21) \\
0.003^{*}\end{array}$ \\
\hline
\end{tabular}

\section{Multivariate Analysis}

Multivariate analysis to analyze the relationship of several independent variables together with the dependent variable. Multivariate analysis was performed using logistic regression test. The variables included in the multivariate analysis were BMI variables, fried food consumption, and physical activity because the $p$-value was $<0.25$ during the bivariate analysis. The results of multivariate analysis can be seen in the Table 4.

\section{Relationship between BMI, Physical Activity and Consumption of Fried Foods with Hyper- cholesterolemia}

The variables included in the multivariate analysis were BMI variables, fried food consumption, and physical activity because the p-value was $<0.25$ during the bivariate analysis. There are 3 models in the multivariate analysis, namely model 1 , model 2 , and model 3 . The model used is model 3 because it is the last model that has been processed from model 1 and model 2 . It can be concluded that statistically, the logistic regression model 3 equation is strong to predict the incidence of hypercholesterolemia.

The result of multivariate analysis from model 3 is that physical activity is the most influential variable with hypercholesterolemia $(\mathrm{RP}=$ $2.55,95 \% \mathrm{CI}=0.88-7.35, \mathrm{p}=0.082$ ). The results of this analysis can be concluded that people who have physical activity $\leq 600-1500$ MET minutes/ week have a 2.55 times greater risk of suffering from hypercholesterolemia compared to people who have physical activity $>1500$ MET minutes/ week. The multivariate results showed that the variable consumption of fried foods $(\mathrm{RP}=5.42$, $95 \% \mathrm{CI}=1.18-16.21, \mathrm{p}=0.003)$ showed a significant relationship with hypercholesterolemia. The results of the multivariate analysis for the magnitude of the risk of consuming fried foods were 5.42 , meaning that people who consumed fried foods $\geq 67$ grams/day had a 5.42 times greater risk of suffering from hypercholesterolemia than those who consumed fried foods $<67$ grams/ day. A study from Budiono (2019) using the Nutriatlet app, a personalized nutrition program instrument showed essential finding that was a decreased body fat percentage, the app is used to ensure the consumption of appropriate foods, athletes should be able to select foods according to their needs so they maintaining body mass index (Budiono, et al., 2019). These results indicate that the variable consumption of fried foods after being analyzed together with the dependent variable, the results show that there is still a significant relationship with hypercholesterolemia.

\section{CONCLUSION}

The factors associated with hypercholesterolemia are BMI, fried food consumption, and physical activity. The most influencing risk factor for hypercholesterolemia is fried food consumption. The advice for students is to maintain normal body weight by exercising regularly so that they can control cholesterol levels. Doing strenuous physical activity that is $25 \%$ of the time spent is sitting or standing and $75 \%$ for activities such as gardening, cycling $(16-22 \mathrm{~km} / \mathrm{hr})$, playing foot- 
ball, playing basketball, gym, and running. Reduce the consumption of fried foods and adopt a healthy diet. For further researchers, they can develop similar research by adding other variables at risk of hypercholesterolemia and using different research designs.

\section{REFERENCES}

Agustiyanti, P. N., Pradigdo, S.F., dan Aruben, R. (2017). Hubungan Asupan Makanan, Aktivitas Fisik dan Penggunaan Kontrasepsi Hormonal dengan Kadar Kolesterol Darah (Studi Pada Wanita Keluarga Nelayan Usia 30-40 Tahun di Tambak Lorok, Semarang Tahun 2017). Jurnal Kesehatan Masyarakat, (e-Journal), 5(4), 737-743.

Budiono, I., Rahayu, T., Soegiyanto, \& Rahmat Kurnia, A. (2019). Use of "Nutriatlet" smartphone application-based personalized nutrition program to improve energy consumption, body mass index, and body fat percentage among martial arts athletes. The Journal of Physical Fitness and Sports Medicine, 8(1), 29-35.

Cariappa KB, S. T. a. H. V. (2017). Sequels of Smoking on Blood Lipid Levels in a Rural Population of South India. Research \& Reviews: Journal of Medical and Health Sciences, 3(2), 23-25.

Dahm, C. C., Chomistek, A. K., Jakobsen, M. U., Mukamal, K. J., Eliassen, A. H., Sesso, H. D., ... Chiuve, S. E. (2016). Adolescent Diet Quality and Cardiovascular Disease Risk Factors and Incident Cardiovascular Disease in MiddleAged Women. Journal of the American Heart Association, 5(12), e003583.

Hanum, Y. (2016). Dampak Bahaya Makanan Gorengan Bagi Jantung. Jurnal Keluarga Sehat Sejahtera, 4(28), 103-114.

Hastuty, Y. D. (2018). Perbedaan Kadar Kolesterol Orang Yang Obesitas Dengan Orang Yang Non Obesitas. Jurnal Kedokteran dan Kesehatan Malikussaleh, 1(2), 47-55.

Hatma, R. D. (2012). Sosial determinan dan faktor risiko kardiovaskuler (analisa data sekunder Riskesda 2007). Buletin Jendela Data \& Informasi Kesehatan, 2(2), 15-21.

Kemenkes. (2018). Remaja Rentan PTM. Mediakom Sehat Negeriku, 96, 1-76.

Kurniawati, F., K. (2015). Hubungan Konsumsi Lemak dan Aktivitas Fisik dengan Kadar Kolesterol Darah dan Kadar Low Density Lipoprotein pada Pasien Penyakit Jantung Koroner Rawat Jalan di Rumah Sakit Umum Daerah Dr. Moewardi. Universitas Muhammadiyah Surakarta

Mello, A. V. de, Pereira, J. L., Leme, A. C. B., Gold- baum, M., Cesar, C. L. G., \& Fisberg, R. M. (2020). Social determinants, lifestyle and diet quality: a population-based study from the 2015 Health Survey of São Paulo, Brazil. Public Health Nutrition, 23(10), 1766-1777.

Ruiz, E., Sandoval, Y., Vizmanos-Lamotte, B., Altamirano martinez, M., Bernabé, A., Goytia, L., ... Rojas, I. (2015). Association between food behavior and hypercholesterolemia-LDL in university students. Nutricion Hospitalaria, 31(6), 2696-2702.

Sari, D., Azrimaidaliza., Purnakarya, I. (2016). Faktor Resiko Kolesterol Total Pasien Penyakit Jantung Koroner Dirumah Sakit Achmad Mochtar Bukittinggi. Jurnal Kesehatan Masyarakat, 4(2), 77-81.

Scherr, C., Fabiano, L. C. C., Guerra, R. L., Belém, L. H. J., Câmara, A. C. G., \& Campos, A. (2018). Sports Practices and Cardiovascular Risk in Teenagers. Arquivos brasileiros de cardiologia, 110(3), 248-255.

Shirazi, S. A. H. (2016). Effect of Exercise on Plasma Cholesterol. Gomal Journal of Medical Sciences, $4(2), 70-73$.

Soleha, M. (2016). Kadar Kolesterol Tinggi dan Faktor-Faktor yang Berpengaruh Terhadap Kadar Kolesterol Darah. Jurnal Biotek Medisiana Indonesia, 1(2), 85-92.

Subhan, F. B., \& Chan, C. B. (2019). Diet quality and risk factors for cardiovascular disease among South Asians in Alberta. Applied Physiology, Nutrition, and Metabolism = Physiologie Appliquee, Nutrition et Metabolisme, 44(8), 886-893.

Sudargo, T., Sari, F. T., \& Naomi, N. D. (2017). The correlation of obesity, smoking, fried foods consumption pattern and food intake with lipid profile in civil servant in Yogyakarta, Indonesia. International Journal of Community Medicine And Public Health, 4(3). 690

Trivedi, R. S., \& Anand, A. K. (2016). Effect of Smoking on Lipid Profile. Gujarat Journal of Otorhinolaryngology and Head and Neck Surgery, 10(2), 13-15.

Waloya, T., Rimbawan, \& Andarwulan, N. (2016). Hubungan Antara Konsumsi Pangan dan Aktivitas Fisik dengan Kadar Kolesterol Darah Pria dan Wanita Dewasa di Bogor. Jurnal Gizi dan Pangan, 8(1), 9-16.

WHO. (2015). What is Moderate-intensity and Vigorous-intensity Physical Activity?, from World Health Organization

Zuhroiyyah, S., Sukandar, H., \& Sastradinanja, S. (2017). Hubungan Aktivitas Fisik dengan Kadar Kolesterol Total, Kolesterol Low-Density Lipoprotein, dan Kolesterol High-Density Lipoprotein pada Masyarakat Jatinangor. Jurnal Sistem Kesehatan, 2(3), 116-122. 